\title{
Effects of Processing and Storage Conditions on Functional Properties of Powdered Blueberry Pomace
}

\author{
Laura Calabuig-Jiménez ${ }^{1}$, Leidy Indira Hinestroza-Córdoba ${ }^{1,2}$, Cristina Barrera ${ }^{1}$ (D) Lucía Seguí ${ }^{1}$ (i) \\ and Noelia Betoret $1, * \mathbb{D}$
}

1 Institute of Food Engineering for Development, Universitat Politècnica de València, Camino de Vera, s/n. CP, 46022 València, Spain; laucajim@alumni.upv.es (L.C.-J.); leihicor@doctor.upv.es (L.I.H.-C.); mcbarpu@tal.upv.es (C.B.); lusegil@upvnet.upv.es (L.S.)

2 Grupo de Valoración y Aprovechamiento de la Biodiversidad, Universidad Tecnológica del Chocó, AA.292, Calle 22 No. 18B-10, Quibdó 270002, Colombia

* Correspondence: noebeval@tal.upv.es

Citation: Calabuig-Jiménez, L.; Hinestroza-Córdoba, L.I.; Barrera, C.; Seguí, L.; Betoret, N. Effects of Processing and Storage Conditions on Functional Properties of Powdered Blueberry Pomace. Sustainability 2022, 14, 1839. https:// doi.org/10.3390/su14031839

Academic Editor: Márcio Carocho

Received: 30 December 2021

Accepted: 1 February 2022

Published: 5 February 2022

Publisher's Note: MDPI stays neutral with regard to jurisdictional claims in published maps and institutional affiliations.

Copyright: (C) 2022 by the authors. Licensee MDPI, Basel, Switzerland. This article is an open access article distributed under the terms and conditions of the Creative Commons Attribution (CC BY) license (https:// creativecommons.org/licenses/by/ $4.0 /)$.

\begin{abstract}
Promoting a circular economy through valorisation of food processing waste into functional ingredients is a challenge today. The combination of hot air drying with milling is a cheap and highly available option for obtaining powdered products from blueberry pomace, a residue with a large amount of fibre and a high proportion of polyphenols from the fruit. The objective of this work was to analyse the effect of drying temperature $\left(60^{\circ} \mathrm{C}\right.$ and $\left.70^{\circ} \mathrm{C}\right)$ and granulometry (coarse and fine) on physicochemical properties, including antioxidant properties and monomeric anthocyanins content. The potential prebiotic effect of blueberry pomace powders, as well as their water and oil interaction properties, were also assessed. Stability of physicochemical properties over 20 weeks of storage was also evaluated. Powders obtained showed a total fibre content higher than $30 \%$ with a good proportion between insoluble and soluble fractions and a high retention of monomeric anthocyanins from fresh pomace $\left(75 \%\right.$ at $60{ }^{\circ} \mathrm{C}$ and $66 \%$ at $\left.70{ }^{\circ} \mathrm{C}\right)$. The powders showed good water interaction properties and interesting technological properties, such as solubility and hygroscopicity, which were not affected by differences in particle size. Stability of powders' physicochemical properties was evidenced throughout the storage period.
\end{abstract}

Keywords: fruit by-products; air drying; milling; antioxidant properties; waste recovery

\section{Introduction}

Increasing concern regarding food loss and food waste and related environmental issues has driven recent actions for the reduction and reuse of food processing wastes. These actions are expected to have an impact on the four 'Food 2030' priorities: nutrition, climate, circularity, and communities, and thus on sustainable development goals [1].

In this context, the concept of sustainable diets, introduced by FAO [2], combines the opportunity of creating a food system that supplies healthy diets for a growing population while reducing its environmental impact. Environmentally sustainable food production has to reconsider wastes as by-products that can be transformed to provide valuable compounds. The use of fruit and vegetable wastes rich in bioactive compounds such as blueberry pomace, to produce functional ingredients of interest to the food industry is an important challenge today.

Blueberries are highly consumed worldwide, being mainly preserved as juices, canned or as puree. The juice industry generates high amounts of pomace (nearly $20 \%$ of the fresh fruit weight), which is not properly reused in the food chain. Blueberry pomace contains between $25 \%$ and $50 \%$ of the different polyphenols that are present in berries [3] and are responsible for the health benefits of this fruit. Anthocyanins and procyanidins identified in blueberry fruit possess antiradical and anti-inflammatory capacity and have been extensively involved in studies about heart disease, skin ageing, metabolic syndrome 
and cancer [4]. Besides, blueberry pomace contains a high percentage of fibre, which plays an important role in preventing diseases through gut microbiota. Fibre fermentation by colonic bacteria generates short chain fatty acids conferring beneficial effects in the host [5]

In order to increase and diversify the consumption of fruit and vegetables, the food industry has shown interest in their use as powdered ingredients for several purposes, including their use as natural and functional ingredients. This is evidenced in the literature not only for fruits and vegetables but also for their wastes or discards [6-9], fruit and vegetable wastes becoming a low-cost source of value-added compounds.

Both processing and storage can cause significant loss of bioactive compounds in fruit and vegetables. Powder manufacturing involves several stages (pretreatments, drying stage and milling conditions) which determine their physicochemical and functional properties, and thus their applications and nutritional properties, including bioactive compounds content and bioaccessibility [9,10]. According to Plazzota et al. [7], drying is a feasible technique to give value to vegetable discards and obtain products with tailored properties, as a result of the drying methods used and the mechanisms involved. On the other hand, both drying and milling (as a pre- or post- treatment) have a significant impact on particle size which in turn significantly influences the powders' properties $[8,11]$. Regarding stability, some studies have shown that high fibre content increases the stability of active components such as anthocyanins during processing. Anthocyanins interact with structural polymeric components present in not clarified juices conferring them stability [12]. Furthermore, low water content and the presence of other polyphenols also contribute to anthocyanins stability.

Obtaining powders from blueberry pomace has already been considered in different research works [13-15]. Gouw et al. [13] studied physico-chemical and functional properties and in vitro gastrointestinal digestion of four different types of fruit powders including powders from blueberry pomace dried at $110^{\circ} \mathrm{C}$ for $3 \mathrm{~h}$. Tagliani et al. [15] used blueberry pomace powder obtained by convective drying at $45^{\circ} \mathrm{C}$, as an ingredient in cookies baked at $170^{\circ} \mathrm{C}$. However, as far as the authors know, there is little information on the impact of air-drying temperature and particle size on the stability of blueberry active components and their evolution during storage.

Therefore, the objective of this work was to analyse the effect of drying temperature and granulometry on physicochemical properties, including antioxidant properties and monomeric anthocyanins, and on water and oil interaction properties of blueberry pomace powders obtained by combining hot air drying with milling. Stability of properties over 20 weeks of storage was also evaluated. In addition, in vitro prebiotic properties of blueberry pomace powders were also assessed.

\section{Materials and Methods}

\subsection{Raw Material}

Frozen organic blueberries (Vaccinium corymbosum var. Duke) of industrial quality were supplied by Samanes S.L (Navarra, Spain). Blueberry juice was obtained as described by Castagnini et al. [16] and the resulting pomace ( $20 \%$ of the fruit) was then collected for the experiments.

\subsection{Process and Storage Conditions}

Blueberry pomace was air dried at either $60^{\circ} \mathrm{C}(\mathrm{DP} 60)$ or $70{ }^{\circ} \mathrm{C}(\mathrm{DP} 70)$ in a convective dryer (POL-EKO model CLW400 TOP, Controltecnica Instrumentación Científica, S.L, Madrid, Spain) until a water activity value lower than 0.3 was reached, which implied different processing times for each temperature (about $270 \mathrm{~min}$ for $60^{\circ} \mathrm{C}$ and $210 \mathrm{~min}$ for $70{ }^{\circ} \mathrm{C}$ ). Dried pomaces were analysed in terms of water activity, moisture content, soluble solids content, colour parameters, monomeric anthocyanins phenols, flavonoids, DPPH and ABTS antiradical activities. According to the slight differences observed in the antioxidant properties between blueberry pomace dried at $60^{\circ} \mathrm{C}$ and $70^{\circ} \mathrm{C}$, and considering the industrial advantages of drying at $70^{\circ} \mathrm{C}$, the effect of further milling was limited to 
blueberry pomace dried at $70^{\circ} \mathrm{C}$. Hence, dried pomace at $70^{\circ} \mathrm{C}$ was milled in a Thermomix ${ }^{\circledR}$ device (Vorwerk, Madrid, Spain) at 10,000 rpm for $10 \mathrm{~s}$ to obtain a coarse powder (CP) and at 10,000 rpm for $2 \mathrm{~min}$, with stops every $30 \mathrm{~s}$, to obtain a fine powder (FP). Powders were then analysed in terms of particle size, fibre content and water and oil interaction properties, in addition to the previously mentioned physicochemical properties also evaluated in the dried (non-milled) pomaces.

Coarse and fine powders were stored for 20 weeks in opaque jars inside a chamber with controlled relative humidity $(24 \%)$ at room temperature $\left(20-22{ }^{\circ} \mathrm{C}\right)$ and in the dark. Every 4 weeks each powder was analysed in terms of moisture content, water activity, colour and antioxidant properties (total phenol content, monomeric anthocyanins content and DPPH and ABTS antiradical activities).

\subsection{Physico-Chemical Determinations}

Water activity was measured with a dew point hygrometer (Aqualab 4TE, Decagon devices Inc., Pullman WA, USA). Water content was calculated from the weight loss of a known amount of sample after drying in a vacuum chamber (Vaciotem, P-SELECTA, Barcelona, Spain) at 0.8 bar and $60{ }^{\circ} \mathrm{C}$ until reaching constant weight [17]. Total soluble solids content of wet samples was calculated from their moisture content and the refraction index of the liquid phase measured in a thermostatic refractometer (ABBE ATAGO, 3-T, Tokyo, Japan) at $20^{\circ} \mathrm{C}$. In the case of dried samples, the refraction index was measured in a 1:10 (w/v) aqueous solution of samples and after that referred to dry matter content. Specific volume was obtained by measuring the volume of a known amount of sample in a test tube. To minimize the air trapped, samples were gently hit until there was no decrease in the total volume.

Colour of samples was measured with a spectrocolorimeter (MINOLTA model CM1000R, Tokyo, Japan) using a D65 illuminant, a $10^{\circ}$ angle of vision and including the shining component. Results were provided in the CIE $\mathrm{L}^{*} \mathrm{a}^{*} \mathrm{~b}^{*}$ system, were $\mathrm{L}^{*}$ is the brightness, $\mathrm{a}^{*}$ is the red-green component and $b^{*}$ is the yellow-blue component. Hue $\left(h_{a b}\right)$ and chrome $\left(C_{a b}\right)$ attributes were also calculated. Results are provided as the average of three triplicates.

Particle size distribution of coarse and fine powders from dried pomace was determined by laser diffraction using a Mastersizer 2000 equipment (Malvern Instruments, Worcestershire, UK). For the dry method, a Sirocco 2000 dispersion unit with air as dispersant at a pressure of $2.5 \mathrm{bar}$ and $60 \%$ speed was employed. For the wet method, the refraction indexes were set at 1.52 for the sample and 1.33 for the dispersed phase (water) and the particle absorption index was 0.1. Particle size was characterized in terms of equivalent volume diameter D [3,4] (De Brouckere mean Diameter), surface area mean diameter D [2,3] (Sauter mean diameter), and the distribution percentiles $d_{10}, d_{50}$ and $d_{90}$, defined as the particle size below which $10 \%, 50 \%$ and $90 \%$, respectively, of the particles are distributed. Results are given as the average of three replicates.

Fibre content was determined by the Van Soest method [18]. This method quantifies the Neutral Detergent Fibre (NDF), the Acid Detergent Fibre (ADF), and the Lignin Detergent Fibre (LDF). The NDF includes lignin, cellulose and hemicellulose; the ADF includes the non-soluble fibre (lignin and cellulose); LDF refers to the lignin content, obtained after acid digestion with $72 \%$ of sulphuric acid. Hemicellulose, cellulose, lignin and total insoluble fibre were calculated from these fractions. Analysis was performed in duplicate, and results expressed as percentage in dried basis.

\subsection{Water Interaction and Oil Emulsifying Properties}

Hygroscopicity of blueberry pomace powders was measured according to the method described by Cai and Corke [19]. It consisted of placing about $2 \mathrm{~g}$ of sample in a hermetic vessel with a saturated solution of $\mathrm{Na}_{2} \mathrm{SO}_{4}\left(\mathrm{a}_{\mathrm{w}}=0.81\right)$ for one week and measuring the weight gained by the sample, expressed as $\mathrm{g}$ of water per $100 \mathrm{~g}$ of sample. Solubility was determined as explained by Mimouni et al. [20] as the ratio between total soluble solids and total solids (TSS:TS) contained in a known amount of sample. TSS were obtained by 
preparing an aqueous solution $(1: 20 \mathrm{w} / \mathrm{v})$ of the sample and drying in a vacuum oven at $63{ }^{\circ} \mathrm{C}$ until constant weight. TS were obtained by centrifuging that same dilution at $4400 \times g$ for $5 \mathrm{~min}$ at room temperature, filtering the supernatant through a Whatman $\mathrm{n}^{\circ}$ 1 filter and drying it in a vacuum oven at $63{ }^{\circ} \mathrm{C}$ until constant weight. Wettability was considered as the time elapsed until $2 \mathrm{~g}$ of sample are completely moistened in a laboratory glass with $20 \mathrm{~mL}$ of water at $25^{\circ} \mathrm{C}$ [21]. Swelling capacity was calculated, according to Raghavendra et al. [22], as the inverse of the ratio between the initial weight of a sample powder diluted in a 1:10 (w/v) aqueous solution and the volume reached by that mixture after $18 \mathrm{~h}$ at $25^{\circ} \mathrm{C}$. Water holding capacity is defined as the amount of water retained by powder without any application of external force. It was calculated from the difference between the weight of the mixture resulting from adding $10 \mathrm{~mL}$ of water to $1 \mathrm{~g}$ of powder and the weight of the same mixture after freeze-drying. Water retention capacity is defined as water content remaining bonded after hydration and centrifugation. For its experimental determination, $1 \mathrm{~g}$ of sample was weighed in a conical centrifuge tube and $10 \mathrm{~mL}$ of water were added allowing hydration for $18 \mathrm{~h}$ at $25^{\circ} \mathrm{C}$. After that, samples were centrifuged for $30 \mathrm{~min}$ at $514 \times \mathrm{g}$. The precipitate was weighed and lyophilized to obtain the dry weight of the sample [22]. Oil holding capacity is defined as the sample capacity to retain oil. It was obtained from the weight gain of a $0.2 \mathrm{~g}$ sample when mixed with $1.5 \mathrm{~g}$ of commercial sunflower oil for $12 \mathrm{~h}$ at room temperature and centrifuged at $1500 \times g$ for 5 min [23]. Emulsifying activity was determined by the method described by Yasumatsu et al. [24]. A $2 \%(w / v)$ aqueous solution was prepared with the sample in a graduated tube. $7 \mathrm{~mL}$ of the prepared solution was mixed with $7 \mathrm{~mL}$ of sunflower oil and homogenized for $5 \mathrm{~min}$ in a vortex at $2400 \mathrm{rpm}$. After that, the mix was centrifuged at $12,857 \times \mathrm{g}$ for $5 \mathrm{~min}$. The volume of the emulsion was measured and referred to total fluid volume. Emulsifying stability was determined by the same procedure explained for emulsifying activity, except that the emulsions were heated at $80^{\circ} \mathrm{C}$ for $30 \mathrm{~min}$ before centrifugation at $514 \times g$ for $5 \mathrm{~min}$. All determinations were performed in triplicate.

\subsection{Antioxidant Properties}

Antioxidants were extracted with an $80 \%(v / v)$ methanol in water solution by $1 \mathrm{~h}$ stirring and further centrifugation at 10,000 rpm for $5 \mathrm{~min}$. The ratio between the weight of sample and the volume of solvent was set at 1:20 (w/v) for the fresh pomace and at 1:100 $(w / v)$ for both the dried pomace and the powders.

Total phenolic content was measured following the Folin-Ciocalteau method [25]. An aliquot of $0.125 \mathrm{~mL}$ of the previously prepared extract was mixed with $0.5 \mathrm{~mL}$ of distilled water and 0.125 of the Folin-Ciocalteau reagent. The mixture was allowed to react for $7 \mathrm{~min}$ in darkness before adding $1.25 \mathrm{~mL}$ of a $7 \%$ sodium carbonate solution to stop the reaction and $1 \mathrm{~mL}$ of distilled water until completing a volume of $3 \mathrm{~mL}$. The mixture was left in darkness for $90 \mathrm{~min}$ and absorbance was measured at $760 \mathrm{~nm}$ in a spectrophotometer (Helios Zeta UV/Vis, Thermo scientific, England). Results were expressed in mg of Gallic Acid Equivalents (GAE) per $100 \mathrm{~g}$ of dry matter.

Total monomeric anthocyanin content was measured according to the $\mathrm{pH}$ differential spectrophotometric method described by Giusti and Wrolstad [26] and Lee et al. [27]. Anthocyanin content was quantified using the molar extinction coefficient for cyanidin-3O-glucoside $\left(2.690 \mathrm{~m}^{2} / \mathrm{mol}\right)$. Buffer solutions were prepared with potassium chlorine at $0.025 \mathrm{M}$ and sodium acetate at $0.4 \mathrm{M}$ were adjusted with chloric acid at $\mathrm{pH} 1$ and at $\mathrm{pH}$ 4.5 , respectively. A volume of $100 \mu \mathrm{L}$ of extract was mixed with $2900 \mu \mathrm{L}$ of each buffer and after $30 \mathrm{~min}$ of reaction, absorbance was measured at $510 \mathrm{~nm}$ and $700 \mathrm{~nm}$. Results were expressed as mg of cyanidin-3-O-glucoside equivalents per $100 \mathrm{~g}$ of dry matter.

Antioxidant activity was measured by both DPPH and ABTS methods. According to the DPPH method [28], an aliquot of $30 \mu \mathrm{L}$ of the extract was mixed with $970 \mu \mathrm{L}$ of a $0.1 \mathrm{mM}$ solution of DPPH in methanol and $2 \mathrm{~mL}$ of methanol. After $60 \mathrm{~min}$ in darkness, absorbance at $517 \mathrm{~nm}$ was measured. Results were expressed in $\mathrm{mg}$ of Trolox Equivalent (TE) per gram of dry matter. 
According to the ABTS method [29], an aliquot of $90 \mu \mathrm{L}$ of the sample was added to $2910 \mu \mathrm{L}$ of the solution ABTS $^{+}$in phosphate buffer with an absorbance of $0.70 \pm 0.02 \mathrm{read}$ at $734 \mathrm{~nm}$. After reacting for 6 min the absorbance of the mixture was measured at $734 \mathrm{~nm}$. Distilled water was used as a reference. Results were expressed in mg of Trolox Equivalent (TE) per gram of dry matter.

All the results are the average of three repetitions.

\subsection{Prebiotic Effect Preliminary Assay: Powders Influence on Lactic Acid Bacteria Growth}

The influence of the blueberry pomace powders on lactic acid bacteria growth was evaluated by adapting the method from Moreno-Vilet et al. [30]. Lactobacillus salivarius spp. salivarius (CECT 4063) was chosen as the probiotic strain. Bacteria cells were incubated in MRS broth (Sharlau Chemie ${ }^{\circledR}$, Barcelona, Spain) at $37^{\circ} \mathrm{C}$ for $24 \mathrm{~h}$, thus constituting the starting inoculum. Coarse or fine powders were added to flasks with MRS broth in the amount needed to reach the following fibre equivalent percentages: $0.5 \%, 1 \%$ and $2 \%(w / v)$. After that, $1 \mathrm{~mL}$ of starting inoculum was added to flasks. In order to correct the possible effect of additional carbon source from the powders due to their sugar content, an amount of glucose (Sharlau Chemie ${ }^{\circledR}$, Barcelona, Spain) equivalent to the soluble solids content of the powders was added to the non-powder-containing MRS broth used as control. All flasks were incubated at $37^{\circ} \mathrm{C}$ for $24 \mathrm{~h}$ and L. salivarius growth was measured by serial dilution and plate counting in double MRS agar layer. Results given are the average of 3 replicates.

\subsection{Statistical Analysis}

Results were statistically analysed with the software Statgraphics (Centurion XVI.I, Statpoint Technologies, Inc., Warrenton, US) with a confidence level of $95 \%$ ( $p$-value $\leq 0.05$ ). Data were processed by simple ANOVA after checking the normality of the data. The processing treatment was considered as the independent factor at five different levels: P-fresh bagasse without processing; DP60-bagasse air dried at $60{ }^{\circ} \mathrm{C}$; DP70-bagasse air dried at $70{ }^{\circ} \mathrm{C}$; FP-bagasse air dried at $70^{\circ} \mathrm{C}$ and milled to fine particle size; CP-bagasse air dried at $70{ }^{\circ} \mathrm{C}$ and milled to coarse particle size. For each processing treatment, three different experiments with three replicates each were carried out, resulting in a total of 45 samples. Significant differences ( $\mathrm{p}$-value $\leq 0.05$ ) among groups were determined by using the Fisher LSD test.

Based on previous results published by other authors, the linear correlation (using Pearson's linear correlation coefficient) between the content of total phenols or monomeric anthocyanins and the antiradical capacity determined by ABTS or DPPH methods was quantified.

\section{Results and Discussion}

3.1. Effects of Processing Condition on Functional Properties of Powdered Blueberry Pomace

\subsubsection{Physico-Chemical Properties}

Water activity, moisture content and total soluble solids of blueberry pomace $(\mathrm{P})$, dried blueberry pomace at $60^{\circ} \mathrm{C}(\mathrm{DP} 60)$ and $70^{\circ} \mathrm{C}$ (DP70) and the coarse and fine powder from dried pomace at $70{ }^{\circ} \mathrm{C}$ (CP and FP respectively) are shown in Table 1 . Air drying was applied until $\mathrm{a}_{\mathrm{w}}<0.3$ to assure stability. Differences between CP and FP evidence that soluble solids content was significantly affected by granulometry. Mechanical disruption during the milling operation causes breakage of macromolecules releasing more soluble chemical structures as milling time increases [31]. 
Table 1. Effect of drying temperature and milling degree on water activity $\left(a_{w}\right)$, moisture content $\left(x_{w}\right)$, soluble solids content $\left(X_{s s}\right)$ and CIEL ${ }^{*}{ }^{*} b^{*}$ colour coordinates of blueberry pomace. Fibre fractions content of blueberry powders are included too.

\begin{tabular}{|c|c|c|c|c|c|}
\hline & $\mathrm{P}$ & DP60 & DP70 & $\mathrm{CP}$ & FP \\
\hline $\mathrm{a}_{\mathrm{w}}$ & $0.989 \pm 0.003^{d}$ & $0.236 \pm 0.004^{c}$ & $0.189 \pm 0.004^{\mathrm{a}}$ & $0.216 \pm 0.004^{b, c}$ & $0.20 \pm 0.06^{b}$ \\
\hline $\mathrm{x}_{\mathrm{W}}(\mathrm{g}$ water $/ \mathrm{g})$ & $0.722 \pm 0.003^{c}$ & $0.032 \pm 0.002^{b}$ & $0.017 \pm 0.002^{\mathrm{a}}$ & $0.017 \pm 0.002^{\mathrm{a}}$ & $0.019 \pm 0.0006^{\mathrm{a}}$ \\
\hline$X_{\mathrm{ss}}(\mathrm{g} \mathrm{ss} / \mathrm{g} \mathrm{dm})$ & $0.283 \pm 0.006^{\mathrm{a}}$ & $0.289 \pm 0.012^{\mathrm{a}}$ & $0.281 \pm 0.011^{\mathrm{a}}$ & $0.340 \pm 0.013^{b}$ & $0.451 \pm 0.012^{\mathrm{c}}$ \\
\hline$L^{*}$ & $26.5 \pm 1.0^{\mathrm{a}}$ & $37.52 \pm 0.15^{b}$ & $37.5 \pm 0.3^{b}$ & $37.5 \pm 0.2^{b}$ & $37.74 \pm 0.13^{b}$ \\
\hline$a^{*}$ & $3.0 \pm 0.3^{\mathrm{a}}$ & $4.3 \pm 0.5^{c}$ & $3.80 \pm 0.10^{b}$ & $3.8 \pm 0.08^{b}$ & $3.37 \pm 0.05^{\mathrm{a}}$ \\
\hline$b^{*}$ & $0.19 \pm 0.3^{\mathrm{a}}$ & $0.70 \pm 0.10^{b}$ & $0.65 \pm 0.09^{b}$ & $0.68 \pm 0.08^{b}$ & $0.99 \pm 0.05^{c}$ \\
\hline$\Delta \mathrm{E}$ & - & $11.1 \pm 0.8^{c}$ & $11.0 \pm 0.7^{\mathrm{c}}$ & $0.06 \pm 0.12^{\mathrm{a}}$ & $0.46 \pm 0.11^{b}$ \\
\hline $\mathrm{C}$ & $3.0 \pm 0.3^{a}$ & $4.3 \pm 0.5^{c}$ & $3.86 \pm 0.08^{b}$ & $3.9 \pm 0.07^{b}$ & $3.93 \pm 0.5^{\mathrm{a}, \mathrm{b}}$ \\
\hline $\mathrm{h}$ & $3.7 \pm 0.7^{\mathrm{a}}$ & $9.2 \pm 0.6^{b}$ & $9.8 \pm 1.5^{b}$ & $10.1 \pm 1.3^{b}$ & $14.6 \pm 0.9^{\mathrm{c}}$ \\
\hline Cellulose (g/100 g dm) & - & - & - & $18.0 \pm 0.4^{b}$ & $16.69 \pm 0.14^{\mathrm{a}}$ \\
\hline Hemicellulose (g/100 g dm) & - & - & - & $12.846 \pm 0.018^{b}$ & $10.444 \pm 0.003^{\mathrm{a}}$ \\
\hline Lignin $(\mathrm{g} / 100 \mathrm{~g} \mathrm{dm})$ & - & - & - & $7.6 \pm 0.2^{b}$ & $6.6 \pm 0.2^{\mathrm{a}}$ \\
\hline Insoluble fibre $(\mathrm{g} / 100 \mathrm{~g} \mathrm{dm})$ & - & - & - & $25.6 \pm 0.8^{b}$ & $23.24 \pm 0.06^{\mathrm{a}}$ \\
\hline Total fibre (g/100 g dm) & - & - & - & $38.5 \pm 0.8^{b}$ & $33.69 \pm 0.06^{\mathrm{a}}$ \\
\hline
\end{tabular}

P refers to the fresh blueberry pomace; DP60 and DP70 refer to the blueberry pomace dried with air at $60{ }^{\circ} \mathrm{C}$ and $70{ }^{\circ} \mathrm{C}$, respectively; and $\mathrm{CP}$ and $\mathrm{FP}$ refer to coarse and fine-grained powders, respectively, obtained by milling the DP70. Different superscript letters $\left({ }^{a}, b, c, d\right)$ in the same row indicate a significant effect of treatment ( $p$-value $\leq 0.05)$. Values are the mean \pm standard deviation of three replicates for water activity, moisture content, soluble solids content and CIEL ${ }^{*}{ }^{*} b^{*}$ colour coordinates and of two replicates for fibre fractions content.

In Table 1, the characteristic colour parameters CIEL*a*b* are shown. The results indicated that colour was significantly affected by drying. Regardless of drying temperature, the lightness $\left(\mathrm{L}^{*}\right)$ significantly increased compared to fresh pomace. Drying also increased coordinates $\mathrm{a}^{*}$ and especially $\mathrm{b}^{*}$, indicating that the colour of dried pomace evolved towards red and yellow, respectively. Water removal and subsequent coloured pigments concentration, together with enzymatic browning and oxidation reactions during drying, contributed to a brownish colour. Hinestroza et al. [32] showed the same results for lulo bagasse, in which the effect of oxidation on colour was confirmed when air-dried bagasse was compared with freeze-dried, which maintained its greenish colour. Colour differences $(\Delta \mathrm{E})$ between dried and fresh pomace evidenced statistically similar colour changes under both temperatures. In the case of powders (FP and $\mathrm{CP}$ ), the colour differences were calculated with the dried pomace at $70{ }^{\circ} \mathrm{C}$ as reference. The differences obtained, although slightly significant, were not visually perceptible. The $C$ values reflect practically the same saturation in all the samples and the higher values obtained for $\mathrm{h}$ in the dry samples and in the powders corroborate an evolution towards more brownish tones as a consequence of the oxidation reactions.

Regarding fibre content, significant higher content was obtained in the coarse powder, for all fibre fractions analysed. This fact could be explained by the stronger milling (same intensity but more time) applied to obtain the fine powder, which affected the structure of the polysaccharide chains, releasing small chain sugars with higher solubility [32]. In both cases, the total fibre content exceeded $30 \%$ by weight with the insoluble fraction approximately twice the soluble one (hemicellulose). This ratio is generally accepted as suitable to provide adequate physiological effect in food ingredients [33]. Compared to other fruit by-products, although total fibre content is similar to that reported for other fruit by-products such as grapefruit peel (44.2\%) [34], mango (37.1\%) and peach (37.6\%) byproducts [35], in general, the blueberry pomace powders exhibited a better ratio between insoluble and soluble fractions.

Particle size distribution for coarse and fine powders by dry and wet methods is represented in Figure 1. Particle size was clearly reduced, and the distribution width increased in fine powders. The differences between dry and wet methods are similar for both granulometries, and reflect the solubilisation of soluble compounds of particles, 
as referred to by Lario et al. [36]. Particle size affects other properties such as water interaction properties. In some cases, a smaller particle size increases the specific surface area, favouring surface adsorption phenomena [22]. In other cases, especially when the fibre is the main component, the mechanical processes can modify the porous structure and affect the hydration properties [36].

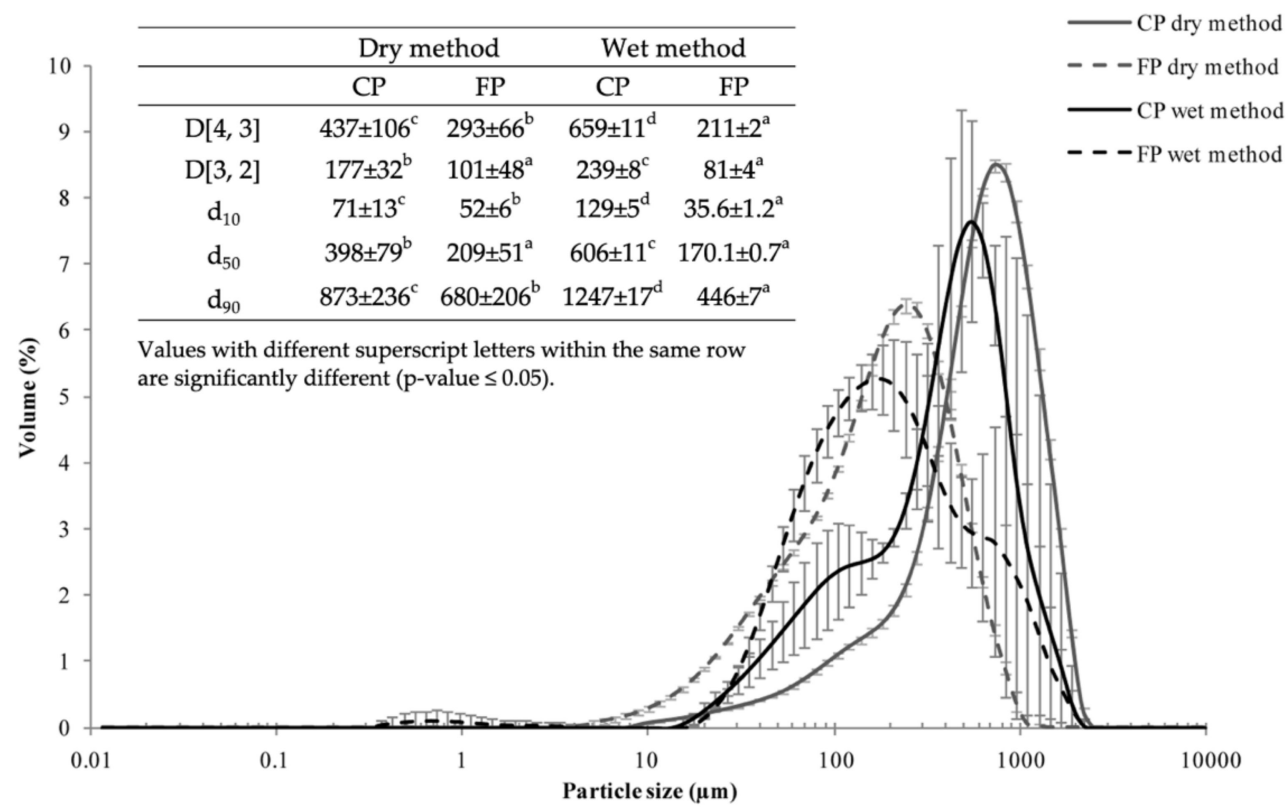

Figure 1. Main characteristic parameters and particle size distribution of coarse (CP) and fine (FP) powders by dry and wet methods. D [3,4]: volume-weighed mean diameter; $\mathrm{D}[2,3]$ : surface area mean diameter; $d_{10}, d_{50}$ and $d_{90}$ : characteristic diameters below which $10 \%, 50 \%$ and $90 \%$ of the particles are included in the distribution. Error bars represent the standard deviation of three replicates.

Particle size distribution and fibre content of powders may affect interaction properties with water or oil determining their hydration and emulsifying properties and consequently their technological properties, and even more, their physiological effect when used as food ingredients [37]. Results for fine and coarse powders are shown in Table 2.

Table 2. Specific volume, solubility, hydration and water retention properties and emulsifying properties of blueberry pomace powders.

\begin{tabular}{ccc}
\hline & CP & FP \\
\hline Specific volume (mL/g) & $9.60 \pm 0.12^{\mathrm{b}}$ & $7.57 \pm 0.06^{\mathrm{a}}$ \\
Solubility (\%) & $31.6 \pm 1.5^{\mathrm{a}}$ & $33.1 \pm 0.7^{\mathrm{a}}$ \\
\hline & Water interaction properties \\
\hline Hygroscopicity (g/100 g) & $61 \pm 3^{\mathrm{a}}$ & $62.7 \pm 1.8^{\mathrm{a}}$ \\
Wettability (s) & $175 \pm 21^{\mathrm{b}}$ & $77 \pm 6^{\mathrm{a}}$ \\
Swelling capacity (mL/g) & $2.88 \pm 0.13^{\mathrm{b}}$ & $2.56 \pm 0.06^{\mathrm{a}}$ \\
Water holding capacity (WHC) (g/g) & $5.1 \pm 0.2^{\mathrm{b}}$ & $4.63 \pm 0.16^{\mathrm{a}}$ \\
Water retention capacity (WRC) (g/g) & $3.4 \pm 0.3^{\mathrm{a}}$ & $3.08 \pm 0.18^{\mathrm{a}}$ \\
\hline & Emulsifying properties \\
\hline Oil holding capacity (OHC) (g/g) & $2.7 \pm 0.6^{\mathrm{a}}$ & \\
Emulsifying activity (\%) & $0.41 \pm 0.13^{\mathrm{a}}$ & $2.9 \pm 0.5^{\mathrm{a}}$ \\
Emulsion stability (\%) & $3 \pm 2^{\mathrm{b}}$ & $0.53 \pm 0.12^{\mathrm{a}}$ \\
\hline
\end{tabular}

$\mathrm{CP}$ and FP refer to coarse and fine powders, respectively, obtained by milling the blueberry pomace dried with air at $70{ }^{\circ} \mathrm{C}$. Values are the mean \pm standard deviation of three replicates. Values with different superscript letters $(\mathrm{a}, \mathrm{b}, \mathrm{c}, \mathrm{d})$ within the same row are significantly different ( $p$-value $\leq 0.05)$. 
The specific volume for both powders is in the range reported by other authors for fruit powders [38]. Significantly higher values were obtained for coarse powder, probably due to its higher porosity compared to fine powder. In general, small particles tend to compact whereas coarse particles facilitate pore creation within particles [39]. Moreover, as stated before, the higher insoluble fibre content of coarse powder may also cause an increase in the specific volume since insoluble fibre is more porous and has lower density than the soluble fibre [37].

Solubility of fruit powders depends on their microstructure, particle size distribution, chemical composition and soluble fibre content [40-42]. Blueberry pomace powders' solubility was relatively low, but in the range of that reported by other authors. Fuentes-Alventosa et al. [43] reported values between $22.6 \%$ and $34.7 \%$ for asparagus fibre. Nevertheless, values obtained by Si et al. [44] for fruit powders such as raspberry powder were notably higher (45.3\%). Results showed no statistically significant differences between coarse and fine powders.

Despite the differences in fibre content between coarse and fine powders, they had no impact on hygroscopicity values. Hygroscopicity is the ability of a product to absorb water from the environment. It determines the stability of the product during storage. Results slightly differ from those reported for Vivek et al. [45] who reported that powders with finer particles have more active pores for water absorption. Results showed no statistically significant differences between coarse and fine powders.

The wettability is strongly affected by size and porosity of particles [42]. Coarse powders had significantly higher wettability than the fine ones probably due to their higher insoluble fibre content and its lower density. Otherwise, the higher porosity of coarse powder facilitates the swelling process [46]. The swelling capacity is related to the satiating effect perceived during the digestive process. Compared with other commercial fruit fibres (such as lemon, peach, orange and apple), whose swelling capacity exceeds $7 \mathrm{~mL} / \mathrm{g}$ [38], the blueberry powders had a quite low swelling capacity. Similar results were obtained for water holding capacity and water retention capacity. Results were significantly higher for coarse powders but lower than those obtained for other fruits such as grape, lemon, orange and apple [35].

Emulsifying properties are affected by the type, size, shape and superficial area of the fibre constituents, but mainly by their chemical compositions [47]. Some compounds like proteins or polysaccharides act as emulsifiers by creating a layer around oil droplets dispersed in an aqueous medium, thereby preventing structural changes such as coalescence, creaming, flocculation or sedimentation. The emulsifying properties such as emulsifying activity and emulsion stability are mainly affected by the hydrophobicity/hydrophilicity ratio and by structural constraints of chemical compounds. Emulsifying activity measures the amount of oil that can be emulsified per unit of sample, whereas emulsion stability measures the ability of the emulsion to resist changes to its structure over a defined time period [48]. However, oil holding capacity refers to a weaker physical entrapment of oil which does not have to be sustained over time. Thus, particle size, composition, and microstructure are some of the factors that can impact this property [49].

Chemical constituents of blueberry powders, particularly the absence of protein and the nature of the polysaccharide chains, cause their emulsifying activity and emulsion stability to be practically nil. Other dehydrated powders from guava and soursop provided higher emulsifying activity which was attributed by authors to its more hydrophobic nature $[50,51]$. The oil holding capacity of the blueberry powders was similar to that obtained in commercial fibres of lemon, peach, orange and apple, as they were in the range from 2.5 to $2.9 \mathrm{~g}$ of oil/g [38]. On the contrary, the blueberry powders have slightly higher values than the powders of grapes, lemon, orange and apple reported by Figuerola et al. [34], which retain less than $2 \mathrm{~g}$ of oil/g. 


\subsubsection{Antioxidant Properties}

Blueberry consumption has been proven to prevent important diseases mainly due to its antioxidant activity [52]. Anthocyanins are the most abundant flavonoid constituents in blueberry fruit, the content in peel being higher than in the juice [53].

In processed products from fresh fruit, the effect of process conditions needs to be evaluated. Anthocyanin degradation has been extensively studied. Although structure, physicochemical properties and the presence of other compounds such as flavones and/or organic acids have an influence, temperature and oxygen are the most important degradation agents. Different authors have demonstrated the degradation of anthocyanins in processing operations in which temperature was equal to or higher than $70{ }^{\circ} \mathrm{C}$ [54]. However, heating around $50^{\circ} \mathrm{C}$ has a positive effect on anthocyanin retention, due to the inactivation of the enzyme polyphenol oxidase [55]. In other cases, while temperature may be not high enough to cause anthocyanins' oxidation by enzymatic action, the presence of oxygen accelerates degradation through a direct oxidative mechanism [56].

Table 3 shows the results obtained in fresh blueberry bagasse $(\mathrm{P})$, that dried by hot air at $60{ }^{\circ} \mathrm{C}(\mathrm{DP} 60)$ and $70{ }^{\circ} \mathrm{C}(\mathrm{DP} 70)$ and the final coarse and fine powders $(\mathrm{CP}$ and $\mathrm{FP}$ respectively). The results have been expressed on a dry basis to avoid deviations from water content.

Table 3. Effect of the drying temperature and the milling degree on total phenols content, monomeric anthocyanins content, and the ability to scavenge radicals DPPH and ABTS in blueberry pomace samples.

\begin{tabular}{cccccc}
\hline & P & DP60 & DP70 & CP & FP \\
\hline $\begin{array}{c}\text { Total phenols } \\
\text { (mg GAE/100 g dm) }\end{array}$ & $4.4 \pm 0.2^{\mathrm{d}}$ & $3.94 \pm 0.10^{\mathrm{c}}$ & $4.48 \pm 0.12^{\mathrm{d}}$ & $2.92 \pm 0.11^{\mathrm{a}}$ & $3.35 \pm 0.10^{\mathrm{b}}$ \\
$\begin{array}{c}\text { Monomeric anthocyanins } \\
\text { (mg glucosid-3-cyanidin/100 g dm) }\end{array}$ & $74.5 \pm 0.4^{\mathrm{d}}$ & $55.5 \pm 0.4^{\mathrm{c}}$ & $48.9 \pm 0.7^{\mathrm{b}}$ & $49.0 \pm 0.9^{\mathrm{b}}$ & $31 \pm 4^{\mathrm{a}}$ \\
$\begin{array}{c}\text { DPPH (mg TE/g dm) } \\
\text { ABTS (mg TE/g dm) }\end{array}$ & $145.0^{\mathrm{m}} \pm 0.6^{\mathrm{d}}$ & $118.6 \pm 0.7^{\mathrm{c}}$ & $102.4 \pm 1.2^{\mathrm{b}}$ & $101.6^{\mathrm{b}} \pm 1.4^{\mathrm{b}}$ & $84 \pm 3^{\mathrm{a}}$ \\
\hline
\end{tabular}

P refers to the fresh blueberry pomace; DP60 and DP70 refer to the blueberry pomace dried with air at $60{ }^{\circ} \mathrm{C}$ and $70^{\circ} \mathrm{C}$, respectively; and $\mathrm{CP}$ and FP refer to coarse and fine-grained powders, respectively, obtained by milling the DP70. Values with different superscript letters $(a, b, c, d)$ within the same row are significantly different $(p$-value $\leq 0.05)$. Values are the mean \pm standard deviation of three replicates.

Drying at $60{ }^{\circ} \mathrm{C}$ retained almost $75 \%$ of the monomeric anthocyanins analysed, and in the case of drying at $70{ }^{\circ} \mathrm{C}$, there was a further $9 \%$ degradation. The retention rates of anthocyanins were much higher than those obtained by other authors who managed to retain only between 5 and $30 \%$ of the initial content of monomeric anthocyanins in whole blueberries when dried with air at $65^{\circ} \mathrm{C}$ in combination or not with microwaves and an $85 \%$ reduction in Saskatoon berries subjected to hot air drying at $75^{\circ} \mathrm{C}$ combined with microwaves [57]. Until now, it has not been possible to elucidate the main mechanisms responsible for the increase in stability detected in some cases. The great variety of chemical structures that make up this group of components and the diversity of compounds with which they establish interactions in different food matrices offer very different results. In this sense, Sadilova et al. [12] observed a higher retention rate of anthocyanins in juices directly squeezed than in juices from concentrates. They attributed the greater stability of anthocyanins in directly squeezed juices to the interaction with components of the polymer matrix such as hemicellulose and pectins. The existence in the pomace of anthocyanins with chemical structures different from those of the juice and a greater retention of these due to the large number of structural polymeric components (cellulose, hemicellulose, lignin, etc.) existing in the pomace may justify the high retention of anthocyanins observed in the present study.

However, although coarse milling did not cause a decrease in the content of monomeric anthocyanins compared with hot air drying at $70{ }^{\circ} \mathrm{C}$, fine milling did cause a significant 
decrease. This significant effect of granulometry could be explained by a greater exposure to oxygen due to the larger specific surface available in fine granulometry [57].

The effect of drying and milling on degradation of the components able to react with the radical DPPH is the same as in the case of monomeric anthocyanins, although the degradation percentages are 5-6\% lower. Several studies $[58,59]$ have found a correlation between the monomeric anthocyanins and the antioxidant activity measured by DPPH assay. In the present study, a Pearson's linear correlation coefficient of 0.97 between the monomeric anthocyanins content and the results of the DPPH test was found. A value of 0.84 was obtained for this coefficient when the linear correlation between the total phenol content and the antiradical capacity determined by ABTS was quantified.

In the case of total phenols, although drying at $60{ }^{\circ} \mathrm{C}$ caused a degradation of $10 \%$, the degradation was null when the drying temperature increased to $70^{\circ} \mathrm{C}$. It could be that at $70{ }^{\circ} \mathrm{C}$ other components are converted into phenol compounds [60]. In cranberry pomace, White et al. [31] observed an increase in flavonol aglycones as a result of deglycosilation by drying at 60 and $80{ }^{\circ} \mathrm{C}$. As reported by Sadilova et al. [60], thermal degradation of anthocyanins involves the formation of chalcone which is degraded into phenolic acids. However, the grinding operation increased the degradation percentage to 24 and $34 \%$, respectively. A larger surface area combined with longer exposure to oxygen would be the main factor responsible for this deterioration.

As for the components capable of reacting with the ABTS radical, the degradation percentage ranged from 31 to $37 \%$. The minimum value was obtained in the case of drying at $70{ }^{\circ} \mathrm{C}$ without milling. In this sense, Bustos et al. [61] evaluated the antioxidant activity with ABTS assay of blackcurrant berry after drying at 50,65 and $100^{\circ} \mathrm{C}$, and found a small difference in the antioxidant activity between drying at $50^{\circ} \mathrm{C}$ and $65^{\circ} \mathrm{C}$.

Bueno et al. [62] estimated anthocyanin intake in the range of $12.5-250 \mathrm{mg} /$ day depending on nutritional, social, and cultural differences of the populations investigated, as well as on the methodological approaches applied. Taking into account that the total monomeric anthocyanins content (spectrophotometrically determined) is $49.0 \pm 0.9 \mathrm{mg}$ cyanidin-3-glucoside/100 $\mathrm{g}$ dry matter in coarse powder, consumption of $5 \mathrm{~g}$ of the product would provide $245 \mathrm{mg}$ of anthocyanins, so it could be assumed that the blueberry pomace powders obtained in this research would contribute a significant proportion of anthocyanins to the daily recommended intake.

\subsubsection{Potential Prebiotic Effect: Powders Influence on Lactic Acid Bacteria Growth}

The results included in this work have shown blueberry pomace as a by-product with a high fibre content. Numerous research works demonstrate the beneficial impact of fibre on health, mainly due to the positive effect on intestinal microbial population [63].

In addition, there are also some studies that show bioactive compounds of berries, and especially dietary flavonoids, have antimicrobial properties very useful in the food industry [64].

In this work, a preliminary test was carried out to clarify the possible use of blueberry pomace powders as a prebiotic. Figure 2 shows Lactobacillus salivarius spp. salivarius growth $(\mathrm{CFU} / \mathrm{mL})$ in MRS broth and in MRS broth enriched with coarse and fine powders at different concentrations after inoculation and incubation for $24 \mathrm{~h}$ at $37^{\circ} \mathrm{C}$. Statistical analysis evidenced that both the granulometry of the powders and its concentration as well as their interaction significantly affected microbial growth ( $p$-value $\leq 0.05)$. 


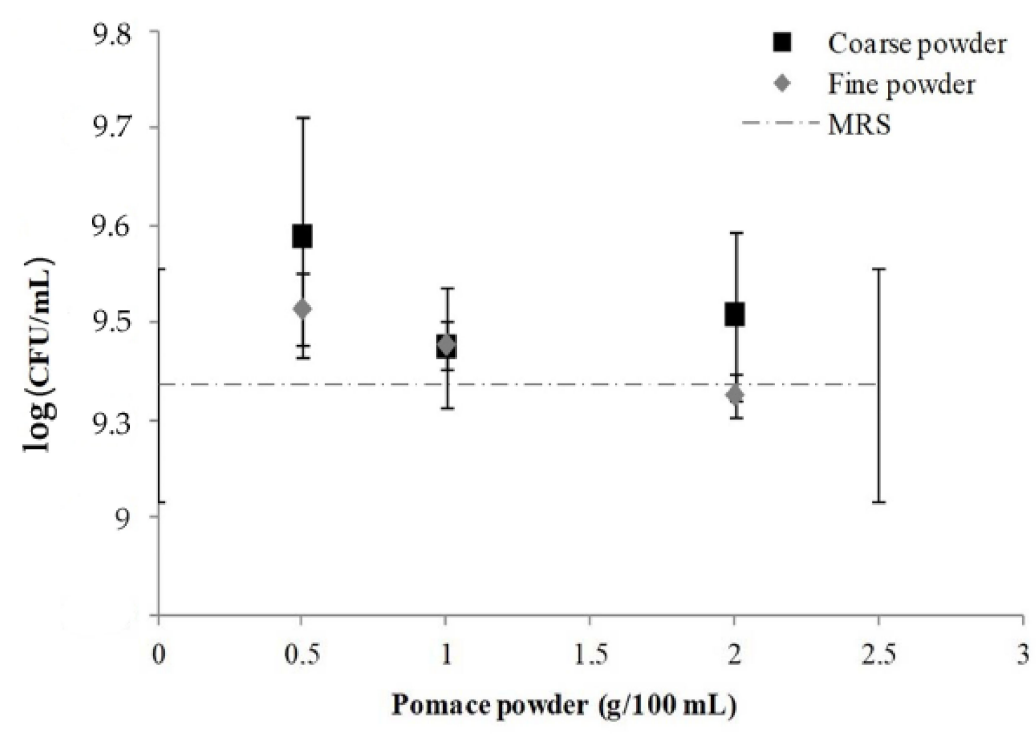

Figure 2. Lactobacillus salivarius spp. salivarius content (CFU/mL) in MRS broth (control) and in MRS broth enriched with coarse or fine powder at different concentrations. Mean \pm standard deviation of three replicates.

The addition of blueberry pomace powder to MRS broth slightly improved the microbial growth, especially when adding $0.5 \%$ of fibre. The slight decrease observed when increasing the percentage of powder added could be due to a greater incorporation of phenolic compounds having antimicrobial properties [65]. In any case, these results, without being conclusive, keep open the possibility of using blueberry pomace powder as a prebiotic ingredient in food.

\subsection{Evolution of Functional Properties of Blueberry Pomace Powders during Storage}

In many cases, the storage is crucial for the physico-chemical and antioxidant properties of foods rich in bioactive components with antiradical capacity. Jackman and Smith [56] established that stability of anthocyanins is strongly influenced by temperature and time of storage. Garcia-Viguera et al. [66] observed much slower degradation of anthocyanins at $20{ }^{\circ} \mathrm{C}$ compared to $37^{\circ} \mathrm{C}$. Additionally, the chemical nature of the specific anthocyanins, as well as their content or interactions with other components such as pectins can be decisive in the degradation of these compounds during storage [67].

\subsubsection{Physico-Chemical Properties}

Table 4 shows physico-chemical properties of coarse and fine powders over 20 weeks of storage. A slight increase in water activity, and consequently in water content, due to slight differences in the relative humidity of the storing air can be observed. Nevertheless, water activity values are kept below or equal to 0.3 , greatly reducing the kinetics of any chemical reaction and thus ensuring the proper stability of the powders.

Colour $\mathrm{L}^{*} \mathrm{a}^{*} \mathrm{~b}^{*}$ coordinates remained practically constant. Only small changes were observed in the $b^{*}$ coordinate of both powders. The slight variations differ depending on the granulometry. This coordinate increased in the coarse powder and decreased in the fine one, indicating that the colour evolved slightly towards yellow and blue colours, respectively. Regarding chroma and hue, the hue was the parameter most affected by the variation of the $b^{*}$ coordinate. Colour differences $(\Delta E)$ calculated with respect to initial time were very small for the two powders, being slightly higher for the fine one. 
Table 4. Water activity $\left(a_{w}\right)$, moisture content $\left(x_{w}\right)$ and CIEL $a^{*} b^{*}$ coordinates of coarse $(C P)$ and fine powder (FP) obtained from dried blueberry pomace at $70{ }^{\circ} \mathrm{C}$ over 20 weeks of storage. Mean \pm standard deviation of three replicates.

\begin{tabular}{|c|c|c|c|c|c|c|c|}
\hline & & 0 & 4 & 8 & 12 & 16 & 20 \\
\hline \multirow[b]{2}{*}{$a_{w}$} & $\mathrm{CP}$ & $0.236 \pm 0.004^{b, c}$ & $0.246 \pm 0.003^{c}$ & $0.231 \pm 0.003^{\mathrm{a}, \mathrm{b}}$ & $0.219 \pm 0.004^{\mathrm{a}}$ & $0.276 \pm 0.014^{\mathrm{d}}$ & $0.311 \pm 0.008^{e}$ \\
\hline & $\mathrm{FP}$ & $0.198 \pm 0.06^{\mathrm{a}}$ & $0.218 \pm 0.01^{\mathrm{a}, \mathrm{b}}$ & $0.254 \pm 0.006^{b, c}$ & $0.305 \pm 0.003^{c, d}$ & $0.315 \pm 0.003^{\mathrm{d}}$ & $0.293 \pm 0.003^{d}$ \\
\hline \multirow{2}{*}{$\begin{array}{c}x_{w} \\
\left(g^{\prime} / g\right)\end{array}$} & $\mathrm{CP}$ & $0.017 \pm 0.002^{\mathrm{a}}$ & $0.024 \pm 0.005^{b}$ & $0.030 \pm 0.005^{b, c}$ & $0.0264 \pm 0.0013^{b, c}$ & $0.029 \pm 0.004^{b, c}$ & $0.032 \pm 0.001^{\mathrm{c}}$ \\
\hline & $\mathrm{FP}$ & $0.0190 \pm 0.001^{\mathrm{a}}$ & $0.023 \pm 0.003^{a}$ & $0.028 \pm 0.002^{b}$ & $0.0300 \pm 0.001^{\mathrm{c}}$ & $0.0343 \pm 0.001^{\mathrm{d}}$ & $0.039 \pm 0.002^{\mathrm{e}}$ \\
\hline \multirow{2}{*}{$\mathrm{L}^{*}$} & $\mathrm{CP}$ & $37.51 \pm 0.26^{\mathrm{a}}$ & $38.04 \pm 0.06^{b}$ & $38.10 \pm 0.22^{b}$ & $37.72 \pm 0.08^{a}$ & $37.49 \pm 0.10^{\mathrm{a}}$ & $37.74 \pm 0.12^{a}$ \\
\hline & $\mathrm{FP}$ & $37.71 \pm 0.12^{c}$ & $36.6 \pm 0.2^{\mathrm{a}}$ & $36.69 \pm 0.04^{a, b}$ & $36.71 \pm 0.12^{\mathrm{a}}$ & $36.78 \pm 0.03^{a, b}$ & $36.85 \pm 0.07^{b}$ \\
\hline \multirow[b]{2}{*}{$a^{*}$} & $\mathrm{CP}$ & $3.80 \pm 0.09^{c}$ & $3.59 \pm 0.03^{a, b}$ & $3.44 \pm 0.08^{\mathrm{a}}$ & $3.73 \pm 0.06^{b, c}$ & $3.67 \pm 0.10^{b, c}$ & $3.81 \pm 0.12^{c}$ \\
\hline & $\mathrm{FP}$ & $3.81 \pm 0.12^{c}$ & $3.49 \pm 0.07^{\mathrm{a}}$ & $3.503 \pm 0.012^{\mathrm{a}}$ & $3.502 \pm 0.012^{\mathrm{a}}$ & $3.53 \pm 0.04^{\mathrm{a}}$ & $3.67 \pm 0.01^{b}$ \\
\hline \multirow[b]{2}{*}{$b^{*}$} & $\mathrm{CP}$ & $0.65 \pm 0.09^{b}$ & $0.44 \pm 0.05^{\mathrm{a}}$ & $0.46 \pm 0.09^{a}$ & $0.77 \pm 0.03^{c}$ & $0.91 \pm 0.02^{\mathrm{d}}$ & $0.99 \pm 0.05^{d}$ \\
\hline & $\mathrm{FP}$ & $0.99 \pm 0.05^{\mathrm{d}}$ & $0.25 \pm 0.2^{\mathrm{a}}$ & $0.41 \pm 0.4^{\mathrm{b}}$ & $0.46 \pm 0.03^{b, c}$ & $0.501 \pm 0.012^{b, c}$ & $0.59 \pm 0.03^{c}$ \\
\hline \multirow{2}{*}{ C } & $\mathrm{CP}$ & $3.86 \pm 0.082^{b}$ & $3.61 \pm 0.03^{a}$ & $3.47 \pm 0.08^{\mathrm{a}}$ & $3.81 \pm 0.06^{b}$ & $3.78 \pm 0.09^{b}$ & $3.86 \pm 0.13^{b}$ \\
\hline & $\mathrm{FP}$ & $3.93 \pm 0.13^{c}$ & $3.45 \pm 0.12^{\mathrm{a}}$ & $3.511 \pm 0.014^{\mathrm{a}}$ & $3.533 \pm 0.012^{\mathrm{a}}$ & $3.721 \pm 0.011^{\mathrm{b}}$ & $3.724 \pm 0.013^{b}$ \\
\hline \multirow[b]{2}{*}{$\mathrm{h}$} & $\mathrm{CP}$ & $14.6 \pm 1.5^{b}$ & $7.0 \pm 0.8^{\mathrm{a}}$ & $7.6 \pm 1.4^{\mathrm{a}}$ & $11.67 \pm 0.5^{b}$ & $14.0 \pm 0.7^{\mathrm{d}}$ & $14.6 \pm 0.2^{\mathrm{d}}$ \\
\hline & $\mathrm{FP}$ & $14.6 \pm 0.2^{\mathrm{d}}$ & $4 \pm 3^{\mathrm{a}}$ & $6.6 \pm 1.3^{b}$ & $7.5 \pm 0.5^{b, c}$ & $8.2 \pm 0.3^{b, c}$ & $9.2 \pm 0.5^{c}$ \\
\hline \multirow{2}{*}{$\Delta \mathrm{E}$} & $\mathrm{CP}$ & - & $0.6 \pm 0.2^{b}$ & $0.72 \pm 0.04^{b}$ & $0.25 \pm 0.19^{\mathrm{a}}$ & $0.29 \pm 0.17^{\mathrm{a}}$ & $0.4 \pm 0.15^{\mathrm{a}, \mathrm{b}}$ \\
\hline & $\mathrm{FP}$ & - & $1.37 \pm 0.18^{b}$ & $1.2 \pm 0.4^{\mathrm{a}, \mathrm{b}}$ & $1.173 \pm 0.110^{a, b}$ & $1.09 \pm 0.13^{a}$ & $0.96 \pm 0.12^{a}$ \\
\hline
\end{tabular}

Values with different superscript letters $(a, b, c, d)$ within the same row are significantly different $(p$-value $\leq 0.05)$ for storage time factor.

\subsubsection{Antioxidant Properties}

Table 5 includes total phenols, monomeric anthocyanins content and antioxidant activity measured by DPPH and ABTS methods. Full stability of all determinations can be observed throughout the storage period. Neither the total phenolic content nor the monomeric anthocyanins content was significantly affected. The antioxidant capacity determined by the two methods also kept their values stable.

Table 5. Total phenols content, monomeric anthocyanins content, and antioxidant activity determined by DPPH and ABTS methods of coarse (CP) and fine (FP) powder from dried blueberry pomace at $70{ }^{\circ} \mathrm{C}$ over 20 weeks of storage. Mean \pm standard deviation of three replicates.

\begin{tabular}{|c|c|c|c|c|c|c|c|}
\hline & & 0 & 4 & 8 & 12 & 16 & 20 \\
\hline Total phenols & $\mathrm{CP}$ & $3.02 \pm 0.12^{\mathrm{a}}$ & $3.12 \pm 0.15^{\mathrm{a}}$ & $3.22 \pm 0.03^{a}$ & $3.12 \pm 0.2^{\mathrm{a}}$ & $3.3 \pm 0.2^{\mathrm{a}}$ & $3.20 \pm 0.13^{a}$ \\
\hline$(\mathrm{mg} \mathrm{GAE} / 100 \mathrm{~g} \mathrm{dm})$ & $\mathrm{FP}$ & $3.36 \pm 0.10^{b}$ & $3.27 \pm 0.11^{\mathrm{a}, \mathrm{b}}$ & $3.05 \pm 0.15^{\mathrm{a}}$ & $3.00 \pm 0.14^{\mathrm{a}, \mathrm{b}}$ & $3.03 \pm 0.18^{a, b}$ & $3.01 \pm 0.3^{\mathrm{a}}$ \\
\hline Monomeric anthocyanins & $\mathrm{CP}$ & $49 \pm 3^{a}$ & $48 \pm 5^{a}$ & $47 \pm 2^{a}$ & $45.1 \pm 1.6^{\mathrm{a}}$ & $47 \pm 3^{a}$ & $49 \pm 3^{a}$ \\
\hline (mg glucosid-3-cyanidin/100 g dm) & $\mathrm{FP}$ & $40 \pm 2^{\mathrm{a}}$ & $44 \pm 3^{a}$ & $40 \pm 3^{a}$ & $43 \pm 2^{a}$ & $40 \pm 5^{a}$ & $43 \pm 3^{a}$ \\
\hline $\mathrm{DPPH}$ & $\mathrm{CP}$ & $101.1 \pm 0.7^{\mathrm{d}}$ & $85.2 \pm 0.9^{b}$ & $91.6 \pm 0.6^{c}$ & $104.9 \pm 0.8^{\mathrm{d}, \mathrm{e}}$ & $107 \pm 3^{\mathrm{e}}$ & $82.7 \pm 1.5^{\mathrm{a}}$ \\
\hline (mg TE/g dm) & $\mathrm{FP}$ & $84.5 \pm 1.9^{b}$ & $87 \pm 2^{b}$ & $86.9 \pm 1.4^{b}$ & $85.5 \pm 0.5^{b}$ & $86.4 \pm 1.5^{b}$ & $76.3 \pm 0.3^{a}$ \\
\hline ABTS & $\mathrm{CP}$ & $58.0 \pm 1.2^{\mathrm{a}}$ & $61 \pm 3^{\mathrm{a}}$ & $60.3 \pm 1.8^{\mathrm{a}}$ & $58 \pm 0.4^{\mathrm{a}}$ & $60.4 \pm 1.9^{\mathrm{a}}$ & $59 \pm 3^{a}$ \\
\hline$(\mathrm{mg} \mathrm{TE} / \mathrm{g} \mathrm{dm})$ & $\mathrm{FP}$ & $62 \pm 1.2^{\mathrm{a}}$ & $62 \pm 1.2^{\mathrm{a}}$ & $63.1 \pm 1.3^{\mathrm{a}}$ & $62.6 \pm 0.5^{\mathrm{a}}$ & $63.37 \pm 0.18^{\mathrm{a}}$ & $61.8 \pm 1.2^{\mathrm{a}}$ \\
\hline
\end{tabular}

Values with different superscript letters $(a, b, c, d)$ within the same row are significantly different $(p$-value $\leq 0.05)$ for storage time factor.

These results differ significantly from those obtained by other authors who studied the effect of processing and storage on the stability of anthocyanins in foods obtained from different berries. Martinsen et al. [67] studied the effect of temperature and storage time on the stability of anthocyanins from strawberry and raspberry jams. The storage time explained more than $42 \%$ of the variability observed in the anthocyanin content in both jams stored for 16 weeks. The losses were greater in strawberry than in raspberry. The authors attributed the greater stability in the monomeric anthocyanins of raspberry jam to the chemical nature of the individual compounds, with higher content in di- and 
triglycosidic substitution. Mazur et al. [68], who obtained similar results, attributed the lower losses to a higher concentration of anthocyanins in the berries used for the study. In another study, increasing anthocyanin concentration by fortification increased the half-life of anthocyanins in strawberry juice from 5 to 12 days [69]. Increased stability at higher concentrations might be due to anthocyanin self-association [70].

Srivastava et al. [71] reported that only $50 \%$ of the anthocyanins were retained in blueberry juices stored for 60 day at $23^{\circ} \mathrm{C}$. Another study evaluated the effects of six months of storage at $25^{\circ} \mathrm{C}$ on monomeric anthocyanins and antioxidant capacity of blueberries that were canned in syrup, in water, pureed and juiced (clarified and not). Storage resulted in dramatic losses in total anthocyanins, ranging from $62 \%$ in berries caned in water to $85 \%$ in clarified juices [72]. In this case, the high water activity and the elimination of pectins and other components that were part of the solid matrix of the fruit, accounted for the high losses observed in the clarified juice. In this sense, several studies show that the interaction with pectins or other structural components of the matrix increases the stability of monomeric anthocyanins [73].

The authors of the present work have not found any published research that demonstrates such high stability of monomeric anthocyanins over 20 weeks of storage of any processed food from berries. It could be because no processed food from berries considered in previous research contained such high amounts of monomeric anthocyanins and fibre together with a water activity as low as that of the blueberry pomace powders obtained in the present work. The high fibre content would ensure retention by chemical interactions which, together with the low water activity, would greatly hinder chemical oxidation reactions.

\section{Conclusions}

The combination of hot air drying with milling produces blueberry pomace powders rich in fibre and phenolic compounds, especially monomeric anthocyanins ( $5 \mathrm{~g}$ of the powder would provide the highest recommended intake for these components). Degradation of bioactive constituents due to processing temperature was not as significant as reported in the literature for other berry-derived products, such as juices or other derivatives rich in pulp. In fact, increasing temperature from $60^{\circ} \mathrm{C}$ to $70^{\circ} \mathrm{C}$ did not result in significant changes in the properties of the dried bagasse. As for the milling intensity, a greater browning and a lower retention of anthocyanins was observed in the fine powder. This could be due to a greater exposure to oxygen derived from the higher specific surface area of smaller size particles. Furthermore, a high stability of the powders was evidenced over the 20 weeks of storage, with no significant changes in any of the properties analysed throughout this period. According to the information available in the literature, the high fibre content, together with the nature of the available anthocyanins, would be the main factors responsible for such high stability.

Structural changes caused by the intense milling of the fine powder (same intensity but more time) resulted in a slight decrease in all fibre fractions and an increased capacity to swell, hold and retain liquid water, which was attributed to a higher specific surface area of the fine powder particles. However, hygroscopicity, more related to changes in material porosity, was not affected by the milling intensity. According to the null emulsifying activity and emulsion stability obtained, the powders are not recommended for the formulation of fat-rich products.

Hence, transformation of blueberry bagasse into powders by combining milling and air-drying is a feasible option to obtain powders rich in bioactive compounds and a remarkable stability, which can be proposed as functional ingredients for the food industry, thus contributing to a circular economy and the development of more sustainable food systems.

Author Contributions: Conceptualization, N.B.; methodology, L.C.-J. and L.I.H.-C.; data curation, L.C.-J.; writing-original draft preparation, L.C.-J. and N.B.; writing-review and editing, N.B., L.I.H.-C.; C.B. and L.S.; funding acquisition, N.B. All authors have read and agreed to the published version of the manuscript. 
Funding: This research was funded by GENERALITAT VALENCIANA, grant number AICO/2017/ '049.

Institutional Review Board Statement: Not applicable.

Informed Consent Statement: Not applicable.

Data Availability Statement: Data are contained within the article.

Acknowledgments: Authors thank the grant provided to Leidy I. Hinestroza by Technological University of Chocó-Colombia [Fortalecimiento de los Encadenamientos Productivos de las Subregiones del Chocó. BPIN 2013000100284].

Conflicts of Interest: The authors declare no conflict of interest.

\section{References}

1. European Commission. Food 2030 Pathways for Action: Research and Innovation Policy as a Driver for Sustainable, Healthy and Inclusive Food Systems; Publications Office of the European Union: Luxembourg, 2020.

2. FAO. The State of the World's Biodiversity for Food and Agriculture, The State of the World's Biodiversity for Food and Agriculture; FAO: Rome, Italy, 2019. [CrossRef]

3. Khanal, R.C.; Howard, L.R.; Brownmiller, C.R.; Prior, R.L. Influence of extrusion processing on procyanidin composition and total anthocyanin contents of blueberry pomace. J. Food Sci. 2009, 74, 52-58. [CrossRef]

4. $\quad$ Al-Awwadi, N.A.; Araiz, C.; Bornet, A.; Delbosc, S.; Cristol, J.P.; Linck, N.; Azay, J.; Teissedre, P.L.; Cros, G. Extracts enriched in different polyphenolic families normalize increased cardiac NADPH oxidase expression while having differential effects on insulin resistance, hypertension, and cardiac hypertrophy in high-fructose-fed rats. J. Agric. Food Chem. 2005, 53, 151-157. [CrossRef] [PubMed]

5. Praveen, M.A.; Parvathy, K.R.K.; Balasubramanian, P.; Jayabalan, R. An overview of extraction and purification techniques of seaweed dietary fibers for immunomodulation on gut microbiota. Trends Food Sci. Technol. 2019, 92, 46-64. [CrossRef]

6. $\quad$ Ferreira, M.S.L.; Santos, M.C.P.; Moro, T.M.A.; Basto, G.J.; Andrade, R.M.S.; Gonçalves, E.C.B.A. Formulation and characterization of functional foods based on fruit and vegetable residue flour. J. Food Sci. Technol. 2015, 52, 822-830. [CrossRef]

7. Plazzota, S.; Calligaris, A.; Manzocco, L. Application of different drying techniques to fresh-cut salad waste to obtain food ingredients rich in antioxidants and with high solvent loading capacity. LWT 2018, 89, 276-283. [CrossRef]

8. Bas-Bellver, C.; Barrera, C.; Betoret, N.; Seguí, L. Turning agri-food cooperative vegetable residues into functional powdered ingredients for the food industry. Sustainability 2020, 12, 1284. [CrossRef]

9. Ramírez-Pulido, B.; Bas-Bellver, C.; Betoret, N.; Barrera, N.; Seguí, L. Valorization of Vegetable Fresh-Processing Residues as Functional Powdered Ingredients. A Review on the Potential Impact of Pretreatments and Drying Methods on Bioactive Compounds and Their Bioaccessibility. Front. Sustain. Food Syst. 2021, 5. [CrossRef]

10. Cilla, A.; Bosch, L.; Barberá, R.; Alegría, A. Effect of processing on the bioaccessibility of bioactive compounds-A review focusing on carotenoids, minerals, ascorbic acid, tocopherols and polyphenols. J. Food Compos. Anal. 2018, 68, 3-15. [CrossRef]

11. Djantou, E.B.; Mbofung, C.M.F.; Scher, J.; Phamba, N.; Morael, J.D. Alternation drying and grinding (ADG) technique, a novel approach for producing ripe mango powder. Food Sci. Technol. 2011, 4, 1585-1590. [CrossRef]

12. Sadilova, E.; Stintzing, F.C.; Kammerer, D.R.; Carle, R. Matrix dependent impact of sugar and ascorbic acid addition on color and anthocyanin stability of black carrot, elderberry and strawberry single strength and from concentrate juices upon thermal treatment. Food Res. Int. 2009, 42, 1023-1033. [CrossRef]

13. Gouw, V.P.; Jung, J.; Zhao, Y. Functional properties, bioactive compounds, and in vitro gastrointestinal digestion study of dried fruit pomace powders as functional food ingredients. LWT Food Sci. Technol. 2017, 80, 136-144. [CrossRef]

14. Hoskin, R.T.; Xiong, J.; Lila, M.A. Comparison of berry juice concentrates and pomaces and alternative plant proteins to produce spray dried protein-polyphenol food ingredients. Food Funct. 2019, 10, 6286-6299. [CrossRef] [PubMed]

15. Tagliani, C.; Perez, C.; Curutchet, A.; Arcia, P.; Cozzano, S. Blueberry pomace, valorization of an industry by-product source of fibre with antioxidant capacity. Food Sci. Technol. 2019, 39, 644-651. [CrossRef]

16. Castagnini, J.M.; Betoret, N.; Betoret, E.; Fito, P. Vacuum impregnation and air drying temperature effect on individual anthocyanins and antiradical capacity of blueberry juice included into an apple matrix. LWT Food Sci. Technol. 2015, 64, 1289-1296. [CrossRef]

17. AOAC. Official Method 973.18. Official Methods of Analysis of the Association of Official Analytical Chemists, 18th ed.; Association of Official Analytical Chemist: Arlington, VA, USA, 2000.

18. Mertens, D.R. Gravimetric determination of amylase-treated neutral detergent fibre in feeds with refluxing beakers or crucibles: Collaborative study. J. AOAC Int. 2002, 85, 1217-1240.

19. Cai, Y.Z.; Corke, H. Production and properties of spray-dried Amaranthus betacyanin pigments. J. Food Sci. 2000, 65, 1248-1252. [CrossRef]

20. Mimouni, A.; Deeth, H.C.; Whittaker, A.K.; Gidley, M.J.; Bhandari, B.R. Rehydration process of milk protein concentrate powder monitored by static light scattering. Food Hydrocoll. 2009, 23, 1958-1965. [CrossRef] 
21. Freudig, B.; Hogekamp, S.; Schubert, H. Dispersion of powders in liquids in a stirred vessel. Chem. Eng. Process. Process Intensif. 1999, 38, 525-532. [CrossRef]

22. Raghavendra, S.N.; Rastogi, N.K.; Raghavarao, K.S.M.S.; Tharanathan, R.N. Dietary fiber from coconut residue: Effects of different treatments and particle size on the hydration properties. Eur. Food Res. Technol. 2004, 218, 563-567. [CrossRef]

23. Garau, M.C.; Simal, S.; Rosselló, C.; Femenia, A. Effect of air-drying temperature on physico-chemical properties of dietary fibre and antioxidant capacity of orange (Citrus aurantium v. Canoneta) by-products. Food Chem. 2007, 104, 1014-1024. [CrossRef]

24. Yasumatsu, K.; Sawada, K.; Moritaka, S.; Misaki, M.; Toda, J.; Wada, T.; Ishii, K. Whipping and Emulsifying Properties of Soybean Products. Agric. Biol. Chem. 1973, 36, 719-727. [CrossRef]

25. Singleton, V.L.; Orthofer, R.; Lamuela-Raventós, R.M. Analysis of total phenols and other oxidation substrates and antioxidants by means of folin-ciocalteu reagent. Methods Enzymol. 1999, 299, 152-178. [CrossRef]

26. Giusti, M.M.; Wrolstad, R.E. Characterization and Measurement of Anthocyanins by UV-Visible Spectroscopy. Curr. Protoc. Food Anal. Chem. 2001, F1.2.1-F1.2.13. Available online: https:// currentprotocols.onlinelibrary.wiley.com/doi/10.1002/0471142913 .faf0102s00 (accessed on 1 December 2021). [CrossRef]

27. Lee, J.; Durst, R.W.; Wrolstad, R.E. Determination of total monomeric anthocyanin pigment content of fruit juices, beverages, natural colorants, and wines by the $\mathrm{pH}$ differential method: Collaborative study. J. AOAC Int. 2005, 88, 1269-1278. [CrossRef] [PubMed]

28. Brand-Williams, W.; Cuvelier, M.E.; Berset, C. Use of a free radical method to evaluate antioxidant activity. LWT Food Sci. Technol. 1995, 28, 25-30. [CrossRef]

29. Re, R.; Pellegrini, N.; Proteggente, A.; Pannala, A.; Yang, M.; Rice-Evans, C. Antioxidant activity applying an improved ABTS radical cation decolorization assay. Free Radic. Biol. Med. 1999, 26, 1231-1237. [CrossRef]

30. Moreno-Vilet, L.; Garcia-Hernandez, M.H.; Delgado-Portales, R.E.; Corral-Fernandez, N.E.; Cortez-Espinosa, N.; Ruiz-Cabrera, M.A.; Portales-Perez, D.P. In vitro assessment of agave fructans (Agave salmiana) as prebiotics and immune system activators. Int. J. Biol. Macromol. 2014, 63, 181-187. [CrossRef] [PubMed]

31. White, B.L.; Howard, L.R.; Prior, R.L. Impact of different stages of juice processing on the anthocyanin, flavonol, and procyanidin contents of cranberries. J. Agric. Food Chem. 2011, 59, 4692-4698. [CrossRef]

32. Hinestroza-Córdoba, L.; Duarte, S.; Seguí, L.; Barrera, C.; Betoret, N. Characterization of powdered lulo (Solanum quitoense) bagasse as a functional food ingredient. Foods 2020, 9, 723. [CrossRef]

33. Lucas-González, R.; Viuda-Martos, M.; Pérez-Álvarez, J.Á.; Fernández-López, J. Evaluation of Particle Size Influence on Proximate Composition, Physicochemical, Techno-Functional and Physio-Functional Properties of Flours Obtained from Persimmon (Diospyros kaki Trumb.) Coproducts. Plant Foods Hum. Nutr. 2017, 72, 67-73. [CrossRef]

34. Figuerola, F.; Hurtado, M.L.; Estévez, A.M.; Chiffelle, I.; Asenjo, F. Fibre concentrates from apple pomace and citrus peel as potential fibre sources for food enrichment. Food Chem. 2005, 91, 395-401. [CrossRef]

35. Amaya-Cruz, D.M.; Rodríguez-González, S.; Pérez-Ramírez, I.F.; Loarca-Piña, G.; Amaya-Llano, S.; Gallegos-Corona, M.A.; Reynoso-Camacho, R. Juice by-products as a source of dietary fibre and antioxidants and their effect on hepatic steatosis. J. Funct. Foods 2015, 17, 93-102. [CrossRef]

36. Lario, Y.; Sendra, E.; García-Pérez, J.; Fuentes, C.; Sayas-Barberá, E.; Fernández-López, J.; Pérez-Alvarez, J.A. Preparation of high dietary fiber powder from lemon juice by-products. Innov. Food Sci. Emerg. Technol. 2004, 5, 113-117. [CrossRef]

37. Elleuch, M.; Bedigian, D.; Roiseux, O.; Besbes, S.; Blecker, C.; Attia, H. Dietary fibre and fibre-rich by-products of food processing: Characterisation, technological functionality and commercial applications: A review. Food Chem. 2011, 124, 411-421. [CrossRef]

38. Martínez-Las Heras, R.; Landines, E.F.; Heredia, A.; Castelló, M.L.; Andrés, A. Influence of drying process and particle size of persimmon fibre on its physicochemical, antioxidant, hydration and emulsifying properties. J. Food Sci. Technol. 2017, 54, 2902-2912. [CrossRef]

39. Forni, S.; Aguilar, I.; Misztal, I. Different genomic relationship matrices for single-step analysis using phenotypic, pedigree and genomic information. Genet. Sel. Evol. 2011, 43, 1-7. [CrossRef]

40. De Moraes Crizel, T.; Hermes, V.S.; De Oliveira Rios, A.; Flôres, S.H. Evaluation of bioactive compounds, chemical and technological properties of fruits byproducts powder. J. Food Sci. Technol. 2016, 53, 4067-4075. [CrossRef]

41. Michalska, A.; Wojdyło, A.; Lech, K.; Łysiak, G.P.; Figiel, A. Effect of different drying techniques on physical properties, total polyphenols and antioxidant capacity of blackcurrant pomace powders. LWT Food Sci. Technol. 2017, 78, 114-121. [CrossRef]

42. Serna-Cock, L.; Torres-León, C.; Ayala-Aponte, A. Evaluación de polvos alimentarios obtenidos de cáscaras de mango (Mangifera indica) como fuente de ingredientes funcionales. Inf. Tecnol. 2015, 26, 41-50. [CrossRef]

43. Fuentes-Alventosa, J.M.; Rodríguez-Gutiérrez, G.; Jaramillo-Carmona, S.; Espejo-Calvo, J.A.; Rodríguez-Arcos, R.; FernándezBolaños, J.; Guillén-Bejarano, R.; Jiménez-Araujo, A. Effect of extraction method on chemical composition and functional characteristics of high dietary fibre powders obtained from asparagus by-products. Food Chem. 2009, 113, 665-671. [CrossRef]

44. Si, X.; Chen, Q.; Bi, J.; Wu, X.; Yi, J.; Zhou, L.; Li, Z. Comparison of different drying methods on the physical properties, bioactive compounds and antioxidant activity of raspberry powders. J. Sci. Food Agric. 2016, 96, 2055-2062. [CrossRef] [PubMed]

45. Vivek, K.; Mishra, S.; Pradhan, R.C. Characterization of spray dried probiotic Sohiong fruit powder with Lactobacillus plantarum. LWT 2020, 117, 108699. [CrossRef]

46. Kethireddipalli, P.; Hung, Y.C.; Mcwatters, K.H.; Phillips, R.D. Effect of Milling Method (Wet and Dry) on the Functional Properties of Cowpea (Vigna unguiculata) Pastes and End Product (Akara) Quality. J. Food Sci. 2002, 67, 48-52. [CrossRef] 
47. López, G.; Ros, G.; Rincón, F.; Periago, M.J.; Martínez, M.C.; Ortuño, J. Relationship between Physical and Hydration Properties of Soluble and Insoluble Fiber of Artichoke. J. Agric. Food Chem. 1996, 44, 2773-2778. [CrossRef]

48. Boye, J.I.; Aksay, S.; Roufik, S. Comparison of the functional properties of pea, chickpea and lentil protein concentrates processed using ultrafiltration and isoelectric precipitation techniques. Food Res. Int. 2010, 43, 537-546. [CrossRef]

49. Farooq, Z.; Boye, J.I. Chapter 11. Novel food and industrial applications of pulse flours and fractions. In Pulse Foods; Brijesh, K., Tiwari Aoife, G., McKenna, B., Eds.; Academic Press: Cambridge, MA, USA, 2011; pp. 283-323.

50. Martínez-Las Heras, R.; Heredia, A.; Castelló, M.L.; Andrés, A. Moisture sorption isotherms and isosteric heat of sorption of dry persimmon leaves. Food Biosci. 2014, 7, 88-94. [CrossRef]

51. Ramírez, A.; Delahaye, E.P. Propiedades funcionales de harinas altas en fibra dietética obtenidas de piña, guayaba y guanábana. Asoc. Intercienc. 2009, 34, 293-298.

52. Konczak, I.; Zhang, W. Anthocyanins-More than nature's colours. J. Biomed. Biotechnol. 2004, 5, 239-240. [CrossRef]

53. Ehlenfeldt, M.K.; Camp, M.J.; Wang, S.Y. $\alpha$-Glucosidase inhibitory activity and antioxidant capacity in the peel and pulp of mixed-species blueberry hybrids. Plan Genet. Resour. 2015, 13, 190-194. [CrossRef]

54. Patras, A.; Brunton, N.P.; O'Donnell, C.; Tiwari, B.K. Effect of thermal processing on anthocyanin stability in foods; mechanisms and kinetics of degradation. Trends Food Sci. Technol. 2010, 21, 3-11. [CrossRef]

55. Skrede, G.; Wrolstad, R.E.; Durst, R.W. Changes in anthocyanins and polyphenolics during juice processing of highbush blueberries (Vaccinium corymbosum L.). J. Food Sci. 2000, 65, 357-364. [CrossRef]

56. Jackman, R.L.; Smith, J.L. Anthocyanins and betalains. In Natural Food Colorants; Springer: Berlin/Heidelberg, Germany, 1996; pp. 244-309. [CrossRef]

57. Kwok, B.H.L.; Hu, C.; Durance, T.; Kitts, D.D. Dehydration Techniques Affect Phytochemical Contents and Free Radical Scavenging Activities of Saskatoon berries (Amelanchier alnifolia Nutt.). J. Food Sci. 2004, 69, SNQ122-SNQ126. [CrossRef]

58. Rodríguez, K.; Ah-Hen, K.S.; Vega-Gálvez, A.; Vásquez, V.; Quispe-Fuentes, I.; Rojas, P.; Lemus-Mondaca, R. Changes in bioactive components and antioxidant capacity of maqui, Aristotelia chilensis [Mol] Stuntz, berries during drying. LWT Food Sci. Technol. 2016, 65, 537-542. [CrossRef]

59. Wu, X.; Gu, L.; Holden, J.; Haytowitz, D.B.; Gebhardt, S.E.; Beecher, G.; Prior, R.L. Development of a database for total antioxidant capacity in foods: A preliminary study. J. Food Compos. Anal. 2004, 17, 407-422. [CrossRef]

60. Sadilova, E.; Carle, R.; Stintzing, F.C. Thermal degradation of anthocyanins and its impact on color and in vitro antioxidant capacity. Mol. Nutr. Food Res. 2007, 51, 1461-1471. [CrossRef]

61. Bustos, M.C.; Rocha-Parra, D.; Sampedro, I.; De Pascual-Teresa, S.; León, A.E. The Influence of Different Air-Drying Conditions on Bioactive Compounds and Antioxidant Activity of Berries. J. Agric. Food Chem. 2018, 66, 2714-2723. [CrossRef]

62. Bueno, J.M.; Sáez-Plaza, P.; Ramos-Escudero, F.; Jiménez, A.M.; Fett, R.; Asuero, A.G. Analysis and Antioxidant Capacity of Anthocyanin Pigments. Part II: Chemical Structure, Color, and Intake of Anthocyanins. Crit. Rev. Anal. Chem. 2012, 126-151. [CrossRef]

63. Espinosa-Martos, I.; Rupérez, P. Indigestible fraction of okara from soybean: Composition, physicochemical properties and in vitro fermentability by pure cultures of Lactobacillus acidophilus and Bifidobacterium bifidum. Eur. Food Res. Technol. 2009, 228, 685-693. [CrossRef]

64. Aly, A.A.; Ali, H.G.M.; Eliwa, N.E.R. Phytochemical screening, anthocyanins and antimicrobial activities in some berries fruits. J. Food Meas. Charact. 2019, 13, 911-920. [CrossRef]

65. Rodríguez Sauceda, E.N. Uso de agentes antimicrobianos naturales en la conservación de frutas y hortalizas. Ra Ximhai 2011, 153-170. [CrossRef]

66. Garcia-Viguera, C.; Zafrilla, P.; Romero, F.; Abellan, P.; Artes, F.; Tomas-Barberan, F.A. Color Stability of Strawberry Jam as Affected by Cultivar and Storage Temperature. J. Food Sci. 1999, 64, 243-247. [CrossRef]

67. Martinsen, B.K.; Aaby, K.; Skrede, G. Effect of temperature on stability of anthocyanins, ascorbic acid and color in strawberry and raspberry jams. Food Chem. 2020, 316, 126297. [CrossRef] [PubMed]

68. Mazur, S.P.; Nes, A.; Wold, A.B.; Remberg, S.F.; Aaby, K. Quality and chemical composition of ten red raspberry (Rubus idaeus L.) genotypes during three harvest seasons. Food Chem. 2014, 160, 233-240. [CrossRef] [PubMed]

69. Garzón, G.A.; Wrolstad, R.E. Comparison of the stability of pelargonidin-based Anthocyanins in strawberry juice and concentrate. J. Food Sci. 2002, 67, 1288-1299. [CrossRef]

70. Castañeda-Ovando, A.; de Pacheco-Hernández, M.L.; Páez-Hernández, M.E.; Rodríguez, J.A.; Galán-Vidal, C.A. Chemical studies of anthocyanins: A review. Food Chem. 2009, 113, 859-871. [CrossRef]

71. Srivastava, A.; Akoh, C.C.; Yi, W.; Fischer, J.; Krewer, G. Effect of storage conditions on the biological activity of phenolic compounds of blueberry extract packed in glass bottles. J. Agric. Food Chem. 2007, 55, 2705-2713. [CrossRef]

72. Brownmiller, C.; Howard, L.R.; Prior, R.L. Processing and storage effects on monomeric anthocyanins, percent polymeric color, and antioxidant capacity of processed blueberry products. J. Food Sci. 2008, 73, 72-79. [CrossRef] [PubMed]

73. Hubbermann, E.M.; Heins, A.; Stöckmann, H.; Schwarz, K. Influence of acids, salt, sugars and hydrocolloids on the colour stability of anthocyanin rich black currant and elderberry concentrates. Eur. Food Res. Technol. 2006, 223, 83-90. [CrossRef] 